\title{
IDENTIFIKASI JAMUR PENYEBAB ONIKOMIKOSIS PADA KUKU KAKI PEMULUNG DI DAERAH TEMPAT PEMBUANGAN AKHIR BANTARGEBANG BEKASI
}

\author{
*Mulyati ${ }^{1)}$, Zakiyah $^{2}$, \\ ${ }^{1}$ Parasitologi FKUI \\ ${ }^{2}$ Program Studi Analis Kesehatan, Fakultas Kesehatan, Universitas Mohammad Husni Thamrin \\ Correspondence author: Mulyati,dramulyati@yahoo.co.id, Jakarta, Indonesia
}

\begin{abstract}
ABSTRAK
Onikomikosis adalah infeksi jamur Dermatophyta, nondermatofita candida dan lainnya yang menyerang daerah kuku jari kaki atau kuku jari tangan. Banyak faktor yang menjadi pemicu terjadinya infeksi onikomikosis diantaranya faktor resiko dan faktor prilaku yang dapat menyebabkan terjadinya infeksi onikomikosis pada pemulung di Tempat Pemuangan Akhir Bantargebang Bekasi.Tujuan dilakukakannya penelitian ini adalah untuk mengetahuikeberadaan jamur penyebab onikomikosis pada kuku kaki pemulung. Metode penelitian ini mengguanakan bahan pemeriksaan berupa kerokan kuku kaki dari 57 orang pemulung. Kemudian dilakukan pemeriksaan langsung dengan $\mathrm{KOH} 20 \%$ dan pemeriksaan Langsung dan biakan didaptkan hasil 87, 72\% positif Dan hasil pemeriksaan biakan didapatkan sepesies jamur yaitu Aspergillus sp 38 koloni (48,72\%), Mucor 13 koloni (16,66\%), Pencillium 12 koloni (15,38\%), Fusarium 3 koloni (3,85\%), Rhizopus 3 koloni (3,85\%), Candida sp 3 koloni (3,85\%), Rhodotorula 3 koloni (3,85\%), Culvularia 2 koloni (2,56\%), Oospora 1 koloni $(1,28 \%)$. Berdsarkan faktor pemicu onikomikosis yang paling tiggi pemulung yang memiliki kelainan kuku 77,19\% dan pemulung yang tidak memiliki kelainan kuku 10,53\%. Pemulung yang bekerja lebih dari 6 jam sebanyak 87,72\% dan pemulung yang bekerja kurang dari 6 jam tidak ditemukan hasil positif. pemulung yang memiliki kebiasaan mencuci kaki dan tidak mencuci kaki didapakan presentase 43,86\%. Pemulung diharapkan dapat meningkatkan kesadaran akan pentingnya kesehatan. Seperti rutinitas mencuci kaki yang bersih setelah bekerja harus menjadi kebiasaan yang dilakukan setiap hari agar dapat menghindari terjadinya onikomikosis.
\end{abstract}

Kata Kunci : Onikomikosis, Kerokan Kuku, Pemulung

\section{ABSTRACT}

Onychomycosis is a fungal infection of Dermatophyta, nondermatophyte candida and others that attack the toenail area or finger nails. Many factors trigger the onychomycosis infection, including risk factors and behavioral factors that can cause onychomycosis infection to scavengers at the Bantargebang Final Disposal Site, Bekasi. The aim of this research was to determine the presence of fungi that cause onychomycosis in scavenger toenails. This research method used material for the examination of nail scraps from 57 scavengers. Then performed a direct examination with $\mathrm{KOH} 20 \%$ and direct examination and culture results obtained 87 , $72 \%$ positive. 12 colonies (15.38\%), Fusarium 3 colonies (3.85\%), Rhizopus 3 colonies (3.85\%), Candida sp 3 colonies (3.85\%), Rhodotorula 3 colonies (3.85\%), Culvularia 2 colonies (2.56\%), Oospora 1 colony (1.28\%). Based on the triggering factors of onychomycosis, the highest scavengers with nail abnormalities were $77.19 \%$ and scavengers without nail abnormalities were $10.53 \%$. There were $87.72 \%$ of scavengers who worked more than 6 hours and those who worked less than 6 hours had no positive results. The percentage of scavengers who have the habit of washing their feet and not washing their feet is $43.86 \%$. Scavengers are expected to raise awareness of the importance of health. For example, the routine of washing clean feet after work must be a habit that is carried out every day in order to avoid the occurrence of onychomycosis.

Keywords: Onychomycosis, Nail Scrub, Scavenger

Open Journal System (OJS): journal.thamrin.ac.id

http://journal.thamrin.ac.id/index.php/anakes/issue/view/35 


\section{PENDAHULUAN}

Infeksi bisa disebabkan oleh beberapa jenis mikrooganisme seperti jamur, bakteri dan virus. Jamur merupakan mikroorgnisme yang termasuk golongan eukariotik dan tidak termasuk golongan tumbuhan. Umumnya jamur dapat tumbuh ditempat lembab tetapi jamur juga dapat menyesuaikan diri dengan lingkungan, sehingga jamur dapat tumbuh dimana saja. Penyakit yang disebabkan oleh jamur disebut mikosis. Jamur dapat menyerang permukaan badan, yaitu kulit, kuku, dan rambut. (Soedarto, 2015)

infeksi kuku yang disebabkan oleh berbagai jenis jamur diseut onikomikosis. Jika infeksi kuku karena jamur dermatophyta disebut dengan istilah tinea Ungium (Monero dan Arenaa 2010). Sedangkan penyebab onikomikosis dapat disebabkan oleh berbagai jenis jamur diantaranya Selain Candida dan Dermatophyta, onikomikosis juga dapat disebabkan oleh Aspergillus sp, Fusarium sp, Chepalosporium sp, Scopulariopsis sp, dan lain-lain (Sulaeman dan Susilo, 2014). Onikomikosis diperkirakan mencakup lebih dari 50\% kelainan kuku dan merupakan kelainan kuku paling sering terjadi (welsh E, Welsh O, Veracaber L, 2010). Prevalensi onikomikoikosis mengalami peningkatan dari 2\% menjadi 14\% dalam 20 tahun terakhir (Queller dan Bathia, 2015). Penelitian ini dilakukan setelah melihat penelitian sebelumnya berjudul pemerikaan kerokan kuku pada pekerja pabrik tahu oleh ( Alda, Novira. 2018) untuk melihat adanya persamaan atau perbedaan dengan penelitian ini. Penelitian ini dilakukan setelah melihat lingkungan dan pekerjaan para pemulung yang memiliki andil dengan terjadinya infeksi onikomikosis. Penulis melakukan penelitian tentang onimikosis pada kuku kaki pemulung didaerah Tempat Pembuangan Akhir (TPA) Bantargebang, Bekasi ini karena banyaknya para pemulung di dekat daerah tempat pembuangan sampah yang kukunya menghitam bahkan rusak, sehingga penulis ingin mengetahui bahwa kuku yang menghitam bahkan rusak tersebut merupakan ciri-ciri dari onikomikosis. Sehingga, penelitian ini dilakukan untuk mengetahui resiko utama yang menyebabkan para pemulung terinfeksi onikmikosis, serta mengetahui apa saja jenis jamur yang dapat menginfeksi sehingga terjadi onikomikosis.

Berdasarkan uraian di atas penulis melakukan penelitian dengan judul "Identifikasi Jamur Penyebab Onikomikosis Pada Kuku kaki Pemulung di daerah Tempat Pembuangan Akhir (TPA) Bantargebang, Bekasi.

\section{METODE}

Tempat Pengambilan sampel di RT 01 RW 05, Kelurahan Ciketing Udik, Kecamatan Bantargebang, Kota Bekasi. Tempat Penelitian sampel: di Laboratorium Mikrobiologi Unversitas MH. Thamrin. Seluruh Pemulung di RT.01 / RW.05 Kelurahan Ciketing Udik, Kecamatan Bantargebang, Kota Bekasi. Sampel Adalah 154 pemulung di RT 01 RW 05 Kelurahan Ciketing Udik, Kecamatan 
Bantagebang, Bekasi yang mengalami kelainan dan tidak sampel dilakukan secara langsung kemudian dilakukan pemeriksaan Biakan menggunakan Agar Sabouroud Dekstrose.

\section{Hasil Pembahasan}

Jumlah sampel kerokan kuku pemulung di daerah Tempat Pembuangan Akhir Bantargebang Bekasi di dalam penelitian ini berjumlah 57 sampel, selanjutnya dilakukan pemeriksaan Langsung menggunakan $\mathrm{KOH} \mathrm{20 \%} \mathrm{dan} \mathrm{biakan} \mathrm{(SDA)} \mathrm{didapatkan} \mathrm{hasil} \mathrm{seperti} \mathrm{tercantum} \mathrm{dalam} \mathrm{tabel} 1$.

Tabel 1.

Hasil Pemeriksaan Langsung (KOH 20\%) dan Biakan pada 57 Sampel Kerokan Kuku Kaki Pemulung di Daerah Tempat Pembuangan Akhir Bantargebang Bekasi

\begin{tabular}{cccc}
\hline \multirow{2}{*}{ Jenis Pemeriksaan } & \multicolumn{2}{c}{ Hasil } & \multirow{2}{*}{ Total } \\
\cline { 2 - 3 } & Positif & Negatif & \\
\hline Langsung (KOH 20\%) & $50(87,72 \%)$ & $7(12,28 \%)$ & $57(100 \%)$ \\
Biakan & $50(87,72 \%)$ & $7(12,28 \%)$ & $57(100 \%)$ \\
\hline
\end{tabular}

Dari tabel 1 dapat diketahui hasil pemeriksaan langsung didapatkan hasil poitif 50 (87,72\%) sampel dan negatif 7 (12,28\%) sampel.Sedangkan hasil pemeriksaan biakan yang positif didapatkan hasil 50 $(87,72 \%)$ sampel dan negative 7 (12,28\%) sampel.

Hasil Elemen jamur yang didapatkan dari Pemeriksaan langsung dengan sampel Kerokan Kuku Kaki Pemulung di Daerah Tempat Pembuangan Akhir Bantargebang Bekasi didapatkan hasil seperti yang tercantum dalam tabel 2.

Tabel 2.

Hasil Elemen jamur yang didapatkan dari Pemeriksaan langsung dengan sampel Kerokan Kuku Kaki Pemulung di Daerah Tempat Pembuangan Akhir Bantargebang Bekasi

\begin{tabular}{lcc}
\hline \multicolumn{1}{c}{ Elemen Jamur } & Jumlah & Persen (\%) \\
\hline Spora & 46 & $80,70 \%$ \\
Sel ragi dan hifa semu & 4 & $7,02 \%$ \\
Tidak ditemukan & 7 & $12,28 \%$ \\
\hline \multicolumn{1}{c}{ Jumlah } & 57 & $100 \%$ \\
\hline
\end{tabular}

Dari tabel 1 dapat diketahui hasil Elemen jamur yang didapatkan pemeriksaan langsung ini didapatkan spora dengan presentase $80,70 \%$, Sel ragi dan Hifa semu didapakan presentase $7,02 \%$ dan kerokan kuku yang tidak ditemukan Elemen jamur sebanyak 12,285.

Hasil pemeriksaan Biakan yang positif pada media SDA terhadap kerokan kuku kaki pemulung di Daerah Tempat Pembuangan Akhir Bantargebang Bekasi didapatkan hasil seperti yang tercantum dalam tabel 3. 
Tabel 3

Hasil Pemeriksaan Biakan pada 50 Sampel yang Positif pada Kerokan Kuku Kaki Pemulung di Daerah Tempat Pembuangan Akhir Bantargebang Bekasi

\begin{tabular}{|c|c|c|}
\hline Jenis jamur yang & Hasil pemeriksaan & $\%$ \\
\hline ditemukan & Positif $(+)$ & \% \\
\hline Aspergillus sp & 38 & $48,72 \%$ \\
\hline Mucor & 13 & $16,66 \%$ \\
\hline Pencillium & 12 & $15,38 \%$ \\
\hline Fusarium & 3 & $3,85 \%$ \\
\hline Rhizopus & 3 & $3,85 \%$ \\
\hline Candida $s p$ & 3 & $3,85 \%$ \\
\hline Rhodotorula & 3 & $3,85 \%$ \\
\hline Culvularia & 2 & $2,56 \%$ \\
\hline Oospora & 1 & $1,28 \%$ \\
\hline Jumlah & 78 & $100 \%$ \\
\hline
\end{tabular}

Berdasarkan tabel 3 dapat diketahui bahwa jamur yang tumbuh dari 50 sampel kerokan kuku yang positif didapatkan sebanyak 78 koloni yang tumbuh berasal koloni tunggal dan koloni campuran. Dan jenis jamur dari sampel kerokan kuku pemulung dibiakan pada media SDA yaitu Aspergillus sp 38 koloni (48,72\%), Mucor 13 koloni (16,66\%), Pencillium 12 koloni (15,38\%), Fusarium 3 koloni (3,85\%), Rhizopus 3 koloni (3,85\%), Candida sp 3 koloni (3,85\%), Rhodotorula 3 koloni (3,85\%), Culvularia 2 koloni (2,56\%), Oospora 1 koloni(1,28\%).

Hasil pemeriksan jamurpenyebab onikomikosis pada sampel kerokan kuku pemulung di Tempat Pembuangan Akhir Bantargebang Bekasi Berdasarkan ada atau tidaknya kelainan pada kuku dapat dilihat dalam tabel 4

Tabel 4

Hasil Pemeriksaan Onikomikosis pada 57 Sampel Kerokan Kuku Kaki Pemulung di Daerah Tempat Pembuangan Akhir Bantargebang Bekasi Berdasarkan Ada Tidaknya Kelainan Kuku

\begin{tabular}{cccc}
\hline \multirow{2}{*}{ Variabel yang diteliti } & \multicolumn{2}{c}{ Hasil } & \multirow{2}{*}{ Total } \\
\cline { 2 - 3 } Adanya Kelainan pada kuku & Positif & Negatif & \\
Ya & $44(77,19 \%)$ & $1(1,75 \%)$ & $45(78,94 \%)$ \\
Tidak & $6(10,53 \%)$ & $6(10,53 \%)$ & $12(21,06 \%)$ \\
\hline Jumlah & $50(87,72 \%))$ & $7(12,28)$ & $57(100 \%)$ \\
\hline
\end{tabular}

Pada tabel 4 dapat dilihat berdasarkan adanya kelainan kuku yang positif jamur onikomikosis yaitu ada 44 Orang $(77,19 \%)$ yang terdapata adanya kelainan kuku dan 6 Orang $6(10,53 \%)$ yang tidak terdapat kelainan kuku. Serta yang hasil negative tidak ditemukan jamur onikomikosis yaitu 1 orang $(1,75 \%)$ yang terdapat kelainan kuku dan 6 orang $(10,53 \%)$ yang tidak terdapat kelainan kuku.

Hasil pemeriksan jamur penyebab onikomikosis pada sampel kerokan kuku pemulung di Tempat Pembuangan Akhir Bantargebang Bekasi Berdasarkan lamanya waktu kerja dalam sehari dapat dilihat dalam tabel 5 


\section{Tabel 5}

Hasil Pemeriksaan Onikomikosis pada 57 Sampel Kerokan Kuku Kaki Pemulung di Daerah Tempat Pembuangan Akhir Bantargebang Bekasi Beradasarkan Lamanya Waktu bekerja dalam sehari

\begin{tabular}{cccc}
\hline \multirow{2}{*}{ Variabel yang diteliti } & \multicolumn{2}{c}{ Hasil } & \multirow{2}{*}{ Total } \\
\cline { 2 - 3 } & Positif & Negatif & \\
\hline Lamanya waktu kerja dalam & & & \\
sehari & & & \\
$>6$ jam & $50(87,72 \%)$ & $7(12,28 \%)$ & $57(100 \%)$ \\
$<6$ jam & $0(0)$ & 0 & 0 \\
\hline Jumlah & $50(87,72 \%)$ & $7(12,28)$ & $57(100 \%)$ \\
\hline
\end{tabular}

(sumber: Data Penelitian, Zakiyah 2019)

Pada tabel 4 dapat dilihat berdasarkan adanya kelainan kuku yang positif jamur onikomikosis yaitu ada 50 Orang $(87,72 \%)$ yang bekerja lebih dari 6 jam dan 0 Orang( $0 \%)$ yang bekerja kurang dari 6 jam. Serta yang hasil negative tidak ditemukan jamur onikomikosis yaitu 7 orang(12,28 \%) yang bekerja lebih dari 6 jam dan 0 orang $(0 \%)$ yang bekerja kurang dari 6 jam.

Dari hasil pemeriksaan Onikomikosis pada sampel kerokan kuku pemulung di Tempat Pembuangan Akhir Bantargebang Bekasi berdasrakan Kebiasaan Mencuci kaki stelah bekerja dapat dilihat dalam tabel 6

Tabel 6

Hasil Pemeriksaan Onikomikosis pada 57 Sampel Kerokan Kuku Kaki Pemulung di Daerah Tempat Pembuangan Akhir Bantargebang Bekasi Berdasarkan Kebiasaan Mencuci Kaki Setelah Bekerja

\begin{tabular}{cccc}
\hline \multirow{2}{*}{ Variabel yang diteliti } & \multicolumn{2}{c}{ Hasil } & \multirow{2}{*}{ Total } \\
\cline { 2 - 3 } & Positif & Negatif & \\
\hline Kebiasaan Mencuci Kaki & & & \\
Ya & $25(43,86 \%)$ & $7(12,28 \%)$ & $32(56,14 \%)$ \\
Tidak & $25(43,86 \%)$ & 0 & $25(43,86 \%)$ \\
\hline Jumlah & $50(87,72 \%)$ & $7(12,28)$ & $57(100 \%)$ \\
\hline
\end{tabular}

Pada tabel 5 dapat dilihat berdasarkan adanya kelainan kuku yang positif jamur onikomikosis yaitu ada 25 Orang (43, $86 \%$ ) yang memiliki kebiasaan mencuci kaki setelah bekerja dan 25 Orang (43, 86 \%) yang tidak memiliki kebiasaan mencuci kaki setelah bekerja. Serta yang hasil negative tidak ditemukan jamur onikomikosis yaitu 7 orang(12,28 \%) yang memiliki kebiasaan mencuci kaki setelah bekerja dan 0 orang $(0 \%)$ yang yang tidak memiliki kebiasaan mencuci kaki setelah bekerja.

Diagnosis onikomikosis pada penelitian ini telah dilakukan dengan pemeriksaan laboratorium dengan cara langsung menggunakan $\mathrm{KOH} 20 \%$ dan dilanjutkan dengan pemeriksaan biakan menggunakan SDA.

Hasil penelitian pemeriksaan jamur penyebab onikomikosis dengan pemeriksaan langsung dan biakan yang telah dilakukan pada 57 pemulung di Tempat Pembuangan Akhir Bantargebang Bekasi pada bulan juni 2019, pada tabel 1 dapat dilihat bahwa didapatkan hasil posiitif $50(87,72 \%)$ sampel dan 
negative $7(12,28 \%)$ sampel. Tingginya angka onikomikosis terhadap pemulung kemungkinan disebabkan karena faktor pekerjaan yang menjadi pemicu utama.

Pekerjaan pemulung jika dilihat dari segi kesehatannya dan keselematan kerjanya, beresiko tinggi untuk terkena berbagai penyakit akibat lingkungan kerja yang kondusif dan kotor. Bukan hal itu saja,supan gizi yang tidak baik memepermudah pemulung terjangkit penyakit seperti batuk, pilek, gatal-gatal, diare dan lain-lain. ( Sari dan Azrin, 2016)

Selain Pekerjaan, tempat tinggal pemulung menjadi faktor utama terjadinya infeksi karena lokasinya yang berada di sekitar TPA. Lingkungan tempat kerja dan tempat tinggal yang kotor para pemulung yang kotor bisa menjadi tempat pertumbuhan jamur penyebab onikomikosis.

Lingkungan kotor akibat pengolahan sampah yang kurang baik menimbulkan kebersihan lingkungan terganggu dan dapat menimbulkan berbagai penyakit bagi masyarakat. Padahal kebersihan dan kesehatan lingkungan merupakan faktor yang sangat penting untuk mencapai kesehatan masyarakat. (Annonymous, 2010)

Hasil pemeriksaan langsung didapatkan elemen jamur yang dapat dilihat pada tebel 2 diaman jumlah spora ditemukan sebanyak $80,70 \%$, sel ragi dan hifa semu banyak 7,02\% dan hasil negatife tidk ditemukan elemen jamur sebanyak 12,28\%,

Hasil pemeriksaan biakan penelitian dapat dilihat pada tabel 3 dimana didapatkan hasil positif sebanyak $87,72 \%$ dengan ditemukannya jamur kapang dan ragi. Jenis jamur yang ditemukan sebanyak 9 spesies yang tumbuh dalam koloni tunggal maupun campuran. Jenis jamur terbanyak sebagai penyebab onikomikosis adalah aspergillus sp 48,72 \% (Aspergillus niger, Aspergillus flavus, Aspergilllus fumigatus dan Aspegillus clavatus), mucor sebanyak 16,66 \%, dan pencillium 15,38\%. Sedangkan jamur kapang dan ragi lainnya tidak menjadi faktor utama infeksi onikomikosis.

Tingginya spesies Apergillus sp yang menjadi penyebab onikomikosis adalah karena Aspergillus sp adalah jamur kontaminan di alam sehingga besar kemungkinan terjadinya kontaminasi dari udara.

Aspergillus sp, Cladosporium, Alterania, Pencillium, dan Stachybotry merupakan beberapa jenis jamur yang biasa ditemui di udara. Sebagian kecil dapat menginfeksi manusia, namun banyak yang dapat tumbuh pada bangunan (Izzah, 2015)Banyaknya spesies jamur tumbuh pada penelitian ini , disebabkan karena banyaknya jenis jamur yang menjadi faktor penyebab terjadinya onikomikosis.Selain Candida dan Dermatophyta, onikomikosis juga dapat disebabkan oleh Aspergillus sp, Fusarium sp, Chepalosporium sp, Scopulariopsis sp, dan lain-lain ( Sulaeman dan Susilo, 2014)

Dilihat dari hasil penelitian oleh (Alda, Novira. 2018) yang memiiki kesamaan dengan penelitian ini yaitu jumlah persentase jamur terbesar yang tumbuh adalah Aspergillus sp sebesar 30,43\%. Dilihat dari tabel 3 yang berisi hasil penelitian onikomikosis berdasarkan kelainan kuku, sebanyak 44 (77,19 \%) sampel positif teridentifikasi onikomikosis karena adanya kelainan pada kuku. Sehingga dapat 
teridentifikasi bahwa kuku yang mengalami kelainan dapat menjadi deteksi awal telah terjadinya infeksi onikomikosis pada kuku.

Sedangkan hasil positif pada kuku yang tidak mengalami kelainan didapatkan 6 (10,53\%) Sehingga kuku yang tidak terdapat kelainan tetapi positif terdapat jamur bisa disebabkan karena kontaminasi dari lingkungan sekitar atau bisa menjadi awal terjadinya infeksi onikomikosis tanpa diiringi kelainan. Kelainan kuku yang ditemukan pada pemulung berupa kuku yang telah mengalami kerusakan, kuku yang menghitam, dan bahkan keseluruhan kuku yang telah mumutih. Temuan Klinis onikomikosis biasanya tidak spesifik dan banyak kelainan kuku yang memperlihatkan gambaran distrofik yang sama seperti trauma pada kuku (Pharaon et al, 2014)

Hasil pemeriksaan onikomikosis berdasarkan lamanya waktu kerja dalam sehari. Dalam tabel dapat dilihat bahwa pemulung yang bekerja lebih dari 6 jam positif terdeteksi onikomikosis sebanyak 50 $(87,72 \%)$ sampel dan hasil negative sebanyak 7 (12,28 \%) sampel.

Karena semua pemulung bekerja lebih 6 jam dapat dilihat bahwa faktor jam kerja menjadi faktor utama terjadinya onikomikosis. Walaupun ada beberapa sampel terdapat hasil negative, akan tetapi jika dibandingkan hasil poitifnya tetap lebih banyak dibandingkan negative. Karena kontak langsung dengan sampah sebagai tempat keberadaan jamur ataupun faktor lingkungan juga akan menjadi faktor utama terjadinya onikomikosis.

Pekerjaan dan aktivitas yang sering berkontak langsung dengan tempat yang kotor, lembab dan basah sangat mendukung untuk berkembang biaknya berbagai macam mikroorganisme. (Zein. 2010)

Namun walaupun faktor lingkungan menjadi faktotr utama, akan tetapi masih banyak faktor lainnya seperti trauma berulang kali pada kuku,penurunan imunitas, faktor gaya hidup seperti penggunaan sepatu terus menerus, olahraga atau kerja berlebihan, serta penggunaan tempat madi umum yang memudahkan terjadinya onikomikosis (Mamuaja, dkk, 2017)

Sedangkan berdasarkan frekuensi mencuci kaki setelah bekerja dapat dilihat bahwa pemulung yang memiliki kebiasaan mencuci kaki dan tidak mencui kaki sama-sama didapatkan hasil positif $25(43,86$ $\%)$.

Dari hasil penelitian dapat dilihat bahwa kegiatan mencuci kaki tidak memiliki pengaruh yang besar terhadap resiko terjadinya onikomikosis. Karena dilihat dari kesehariannya pemulung setelah mereka mencuci kaki mereka tidak menggunakan alas kaki dan juga dapat disebabkan karena kegiatan muncuci kaki yag dilakukan tidak maksimal, sehingga kaki masih kotor.

Karena selain menjaga kebersihan pribadi, kita berkewajiban utuk menjaga kesehatan lingkungan rumah kita dengan menerapkan konsep pola hidup sehat. Syarat utama dari sebuah rumah yang sehat adalah mampu mendukung kesehatan penghuninya. Beberapa hal diantaranya adalah tersedianya air bersih, memiliki tempat pembuangan sampah, dan menjamin tersedianya udara bersih. (Iswanto, 2009) 
Faktor predisposisi yang memudahkan terjadinya onikomikosis ialah kelembaban, oklusi, trauma berulang pada kuku, penurunan imunitas, Jenis kelamin, usia lanjut, kanker, psoriasis dan hyperhidrosis yang juga merupakan faktor resiko. (Richardson MD, Warnock Dw, 2012) 


\section{SIMPULAN}

hasil pemeriksaan biakan ditemukan 9 spesies jamur yaitu Aspergillus sp 48,72\%, Mucor 16,66\%, Pencillium 15,38\%, Fusarium 3,85\%, Rhizopus 3,85\%, Candida sp 3,85\% , Rhodotorula 3,85\%, Culvularia 2,56\%, Oospora 1,28\%. faktor kelainan kuku yang menjadi pemicu infeksi onikomikosis. Yaitu pemulung yang memiliki kelainan kuku 77,19\% dan pemulung yang tidak memiliki kelainan kuku $10,53 \%$. Faktor perilaku mencuci kaki setelah bekerja, pemulung yang memiliki kebiasaan mencuci kaki dan tidak mencucii kaki sama-sama didapatkan presentase 43,86 \% dengan total presentase sebesar $87,72 \%$. Faktor lain seperti lamanya jam kerja Pemulung yang bekerja lebih dari 6 jam sebanyak 87,72\% dan pemulung yang bekerja kurang dari 6 jam tidak ditemukan hasil positif.

\section{UCAPAN TERIMA KASIH}

Penulis mengucapkan terima kasih kepada Prodi D III Analis Kesehatan Universitas MH Thamrin berperan serta dalam penelitian ini.

\section{DAFTAR PUSTAKA}

1. Annonymous. Profil Kesehatan Provinsi Jawa Tengah. 2010

2. Alda, Novira. Pemeriksaan jamur pada kerokan kuku tangan dan kuku kaki kayawan pabrik tahu di jalan baru kemang pd Udik kemang Bogor Jawa Barat. Universitas MH. Thamrin. 2018

3. Ameen et al. British Association of Dermatologists gidelines for the management of onychomycosis 2014. British Journal of Dermatology. 2014

4. Evan R, Hu SW, Mee SA, Chris A. Candida parapsilosis of the nail bed without onychomycosis. Doj. 2015.

5. Grover C, Khurana A. Onychomycosis: Newer insights in pathogenesis and diagnosis. Indian J Dermatol Venereol Leprol [serial online] 2012.

6. Graham, Robin dkk, Lecture Notes On Dermatology. Jakarta. 2009.

7. Gupta AK, Simpson FC, Diagnosing Onycochomycosis Clinic in Dermatology, 2013.

8. Harahap. Kelainan Kuku Ilmu Penyakit kulit, Hipokrates. Jakarta. 2000.

9. Iswanto. Pola Hidup Sehat Dalam Keluarga. Sunda Kelapa Pusatak. Jakarta. 2009

10. Izzah, N. Kualitas udara di lingkungan. Fakultas Sains dan Teknologi UINS Hidayatulah. Jakarta. 2015.

11. Kaur et al. Onychomycosis-Epidemiology. Diagnosis and management. Indian journal of medical Microbiology. 2010.

12. KR Deddy, Jurnal Gandaki Medical College-Nepal. 2017.

Open Journal System (OJS): journal.thamrin.ac.id 
13. Monero G, Arenas R. Other Fungi Causing Onychomycosis Clinic in Dermatology. 2010

14. Muamuja, Enricco.H.,dkk Onikoikosis Kandida Yan Diterapi Dengan Itrakonazol Dosis Denyut, Lporan Kasus, Fakultas Kedokteran Universitas Sam Ratulangi, Manado, 2017.

15. Mulyati. Buku Penutun Praktikum Mikologi. Universitas MH. Thamrin. 2018.

16. Murniana, Antifungal Activity From Seed Of Cereba Odollam Against Candida albicans. Jurnal Natural, 2011.

17. Pharaon et al. Onichomycosis journal. 2014.

18. Piraccini BM, Alessandrini, A Onychomycosis: A Review Journal of Fungi, 2015.

19. Pohan, Arthur. Bahan Kuliah Mikologi FK UNAIR. Surabaya. 2013.

20. Queller JN, Bhatia N. The Dermathologist Approach to Onychomycosis. Jurnal Of Fungi. 2015

21. Richardson MD, Warnock Dw. Fungal Infection Diagnosis and Management. 2012

22. Rieder E, Hu S, Meehan S, Adigun C. Candida parapsilosis of the nail-bed without onychomycosis. Dermatology Online Journal. 2015.

23. Robert D, Taylor W, Boyle J. Guidelines For Treatment Of Onychomycosis. Br J Dermatol.2009

24. Sari I.K, Azrin M. Gambaran Pengetahuan Pemulung terhadap Aspek Kesehatan Keselamatan Kerja dalam Pengelolaan Sampah di Tempat Pembuangan Sementara. 2016

25. Soedarto. Mikrobiologi Kedokteran. Sagung Seto. Jakarta. 2015

26. Sulaeman, JR dan Susilo, L., Mikosis Superfisial bukan Dermatofitosis, Buku Penuntun Parasitologi Kedokteran, Edisi Keempat, FKUI, Jakarta, 2014.

27. Subakir. Jurnal Dermatomikosis Superfisialis. 2010

28. Swastika, Made, Basic Sciences and Terapeutic in Regenarative and Aesthetic Medicine. Departemen Ilmu Kesehatan Kulit dan Kelamin Fakultas Kedokteran Universitas Udayana RSUP Sanglah, Denpasar, Bali, 2017.

29. Welsh O, Vera-Carera L, Welsh E. Onychomycosis Clinic In Dermatology. 2010.

30. Zein. Faktor Resiko Infeksi Akut Pada Orang Dewasa. 2010.

Open Journal System (OJS): journal.thamrin.ac.id 